\title{
Analysis of Resource Use Efficiency in Small-Scale Maize Production in Tafawa-Balewa Local Government of Bauchi State Nigeria
}

\author{
${ }^{1}$ Shehu U. A, ${ }^{2}$ Ibrahim A. I., ${ }^{3}$ Hassan T., \& ${ }^{4}$ Bello M \\ ${ }^{1,2,3 \& 4}$ Agricultural Education Department School of Undergraduate Studies, P. M. B. 44, College of Education \\ Azare, Bauchi State, Nigeria
}

\begin{abstract}
This paper analyzed the resource-use efficiency of small-scale Maize production in Tafawa-Balewa local government area of Bauchi State. Data were collected from a sample of 120 Maize farmers selected through multi-stage sampling procedure using questionnaire and analyzed using simple descriptive statistics, double-log function and marginal value productivity analysis. The result showed that $90.17 \%$ had formal education; $51.67 \%$ were males; $90.17 \%$ were between the ages of 21-50. Majority $72.50 \%$ were married. In terms of farming experience, majority (86.67\%) of the respondent had farming experience between 5-20 years. $75.00 \%$ had no contact with extension. The double-log function gave the best fit with Adjusted $R^{2}$ of $81.16 \%$. Production inputs such as seed, fertilizer, labour affected output significantly. Maize production in the study area has an increasing return to scale from the sum of elasticity of production (1.747). Seed and fertilizer were underutilized in Maize production, whereas labour was over used. The major problem confronting the farmers include high cost of inputs (77.50\%); Untimely disbursement of credit/inputs (62.50; inadequate extension services (59.17); unstable price (41.67\%); draught (33.33\%), inadequate credit facilities (31.67\%) etc. Profit could be enhanced by increasing the quantity used of seed and fertilizer inputs, its timely supply. Labour should be reduced to optimum level for increase output and total revenue respectively. It is also recommended that extension education and financial support to farmers be improved to allow them increase output and total revenue. There is need for adjustment in resource use in order to improve farm profit at this level of technology used by Maize farmers in the study area.
\end{abstract}

Keywords: Resource Use Efficiency, Profitability, Small Scale, Maize, Tafawa Balewa

\section{Introduction}

Agriculture constitutes a significant sector of Nigeria's economy (Adebowale, 2014). The sector is significant in terms of employment of labour, contribution to Gross Domestic Product (GDP) and until early 1970, agricultural exports were the main sources of foreign exchange earnings (Amaza and Olayemi, 2002). During the 1960s, the growth of the Nigerian economy was derived mainly from the agricultural sector. However, in recent years, there has been a marked deterioration in the performance of Nigeria's agriculture. There is a widening gap between demand and supply for food materials (Cereals, Maize inclusive) that aggravated food problem in the country (Olayide, 1982). Kalu (1994) revealed that agricultural production was about 26\% lower than the level in 1974 and the staple food production (Maize inclusive) fell by $45 \%$. The decline in export crop production, the low level of agricultural technology, low investments, and inefficient utilization of farm inputs, drought and post harvest losses largely contributed to the poor performance of agricultural sector (Umar, 2011).

Agriculture has to be given the needed impetus to make it become the mainstay of the Nigerian economy and for it to make a meaningful contribution toward the economic development of the country through increased Maize production. There is a growing emphasis on the need for rapid development of the agricultural sub-sector in Nigeria, which is today dominated by subsistence farmers. Increase in the productivity of Maize is required to achieve a minimal level of food security since Maize is the second most popular cereals grown in northern Nigeria (Hamidu, 2002).Maize (Zea mays L) is an annual crop of great importance, it was domesticated from America. It is used as a source of carbohydrate to both human (in the developing countries) and animal feed worldwide due to its high feeding value (Undie et al., 2012) it is recently used in production of biofuel. It is equally well accepted for feed ingredient and can contribute up to 30\% protein, 60\% energy, and $90 \%$ starch in animal diet (Dado, 1999). Maize is one of the important crops occupying third position next to wheat and rice in cereal production in the world (Amos, 2012). Maize has been recognized as a common component in most intercropping system. It seems to lead as the cereal constituent of intercrop and is regularly combined with dissimilar legumes (Maluleke et al., 2005). Maize yield is generally higher in high solar intensities, lower night temperatures and lower incidence of pest and diseases (Adesoji, et al., 2013). 
To achieve optimum production level, resources available must be used efficiently. Successful planning and result-oriented policies require the technical knowledge of productivities of farm resources to know the needed necessary adjustments to achieve a correct input mix (Jirgi, 2002). Despite its importance, Maize production in Nigeria is predominated by traditional smallholders who use traditional methods of production. Resources are underutilized in addition to use of low yielding varieties, poor extension services, inadequate incentives and amenities, which give rise to low output and hence low farm income (Jirgi, 2002). Umar (2011) examined resource use efficiency in small-scale Cowpea production in Katagum Zone of Bauchi State the results from the farm budgeting analysis revealed that total cost of production incurred by each respondent was \# 22,564.03/ha while the total variable cost was $\$ 22,130.97 /$ ha. Labour constituted $44.14 \%$ of the average total cost of production. The total average revenue per respondent was $35,675.00 / \mathrm{ha}$, while the average gross margin was found to be $\$ 13,544.03$ per hectare; operating and gross ratios were 0.6203 and 0.6324 respectively. The double-log production function gave the best fit with $\mathrm{R}^{2}$ of $48.6 \%$. The double-log production function revealed that, three (3) of the coefficients of the inputs had positive and significant relationship with the farmers total output, while farm size and labour have negative insignificant coefficients. The sum of the elasticities of production with respect to all the inputs was 0.8834 . This indicates decreasing return to scale.

Umar (2011) examined resource use efficiency in small-scale Sorghum production in Katagum Local Government of Bauchi State the result showed that $52.59 \%$ had formal education; $68.15 \%$ were males; $77.78 \%$ had no contact with extension while about $45.19 \%$ had less than 6 years farming experience. The double-log function gave the best fit with $\mathrm{R}^{2}$ about $68 \%$. Production inputs such as seed, fertilizer, labour affected output significantly. Sorghum production in the study area has an increasing return to scale from the sum of elasticity of production (1.318). Seed and fertilizer were underutilized in sorghum production, whereas labour was over used. Alimi (2000) studied the resource use efficiency in food crop production in Oyo State. The results from his study revealed that the identified resources (land, labour and capital) were used within the rational range but not at economically optimal level. Only hired labour was used close to economic optimal level. Other notable problems of Maize production include inappropriate decision on how best to allocate resources, inadequate use of corresponding production inputs and inadequate adoption of improved technologies by farmers, erratic dryspell and drought (Stephen et al, 2004). In addition, farmers might use resources rationally but not at economic optimal level, all these contribute to low output. Therefore, it is proper to examine the resource use efficiency and productivity of small-scale Maize in the study area.

\section{Objective Of The Study}

The study was undertaken to analyze the efficiency of resource-use in Maize production in Tafawa-balewa local government area of Bauchi State.

The specific objectives of the study were:

1. To examine the socioeconomic characteristics of Maize farmers,

2. Determine input-output relationship of Maize production,

3. Determine the resource-use efficiency in Maize production.

4. Determine constrains to s Maize production faced by Maize farmers.

\section{The Study Area}

\section{Methodology}

The study area was Tafawa-balewa local government area of Bauchi State created in 1976 during the local government reform with the total land area of about $213 \mathrm{sq} \mathrm{km}$. It is virtually located toward the southwestern part of Bauchi State and is about 50 kilometers away from the state capital. It is bounded by plateau State from the south-west and three other locals' areas that include Dass to the east, Toro to the north and Bauchi to the northeast. The climate of the area is that of tropical wet and dry, with wet season lasting for about four to five (4-5) months. Temperatures of the area are generally high, especially around April and May when they attain a level of about $33-38^{\circ} \mathrm{C}$, compared with November to February when the level drop to about 22 to $25^{\circ} \mathrm{C}$. Total annual rainfall ranges from $900 \mathrm{~mm}-1050-\mathrm{mm}$. potential evapo-transpiration rate is generally high, values reaching up to $5.1 \mathrm{~mm} /$ day. The northeast trade winds sweep the zone between Octobers and may bringing dryness to the area.The land in the local government has a hilly topography, which is about $410 \mathrm{~m}$ above mean sea level. Christianity is the dominant religion in the study area. The local government area has a population of 219,988 people (NPC,2006). This figure comprises of various tribes but notable among them are the Sayawas's, Jarawa's, Hausa's, Fulani's and Ngas's. However, Sayawas's is the most commonly used language in the study area. The people of the local government are predominantly farmers and they cultivate crops such as maize, sorghum, cassava, wheat, rice, sugarcane, groundnut etc. 


\section{Sampling Technique}

Multi-stage sampling technique was used to get respondents in the study area. The local government is made up of Lere, Bula and Tafawa-balewa district and two (2) districts were purposively selected because if their prominence in Maize production. From the sampled districts three (3) villages were randomly selected and Twenty (20) farmers were randomly sampled from each from each of the villages selected. Therefore, a total of one hundred and twenty (120) farmers were randomly sampled from the six villages throughout the research period. The sampled villages include Zango, Marti, Bununu, Shal, Dunga and Tafawa-balewa. Structured questionnaire was used to collect data from the farmers on inputs, costs, output and income during the 2015 production season. Data on socioeconomic variables such as age, sex, farm size and farming experience were also collected.

\section{Data Analytical Techniques}

Descriptive statistics was used to describe the socio-economic characteristics of farmers. Regression model was used to determine input-output relationship; efficiency of resource-use was determined using marginal value productivity and marginal factor cost ratio. The implicit form of regression model is given by:

$$
\begin{aligned}
& \mathrm{Y}=\mathrm{f}\left(\mathrm{X}_{1}, \mathrm{X}_{2}, \mathrm{X}_{3}, \mathrm{X}_{4}, \ldots \ldots \ldots \mathrm{X}_{\mathrm{n}}\right) \mathrm{u} \ldots \ldots \ldots \ldots \ldots \text { (i) } \\
& \text { Where, } \\
& \mathrm{Y}=\text { output in kilogram }(\mathrm{kg}) \\
& X_{1} \ldots X_{\mathrm{n}}=\text { variable inputs used during production process, } \\
& \mathrm{U}=\text { random error term or random disturbance term. }
\end{aligned}
$$

In addition, the explicit form of the model is given by:

$$
\mathrm{Y}=, \beta_{\mathrm{o}}+, \beta_{1} \mathrm{X}_{1}+, \beta_{2} \mathrm{X}_{2}+, \beta_{3} \mathrm{X}_{3}+, \beta_{4} \mathrm{X}_{4}+\ldots \ldots \ldots \ldots, \beta_{\mathrm{n}} \mathrm{X}_{\mathrm{n}}+\mathrm{u}
$$

Where

$\beta_{0}=$ Intercept or constant parameter,

$\beta_{1} \ldots . ., \beta_{n}=$ the regression coefficients of the independent variables,

$\mathrm{X}_{1} \ldots \mathrm{X}_{\mathrm{n}}=$ Independent variables used,

$\mathrm{U}_{\mathrm{i}}=$ Stochastic disturbance term.

Linear, exponential, semi-log and double-log forms of the production function were fitted to the data. The double-log function revealed the best fit and was therefore, chosen as the lead equation based on the number of entities that were significant, Size of $\mathrm{R}^{2}$ and F-Ratio, stochastic error term and the contributions made by the coefficients(Adedeji, 2015).

The Double-log lead equation is expressed in its explicit form as:

$$
\operatorname{LnY}=\ln , \beta_{\mathrm{o}}+\ln , \beta_{1} \mathrm{X}_{1}+\ln , \beta_{2} \mathrm{X}_{2}+\ln , \beta_{3} \mathrm{X}_{3}+\ln , \beta_{4} \mathrm{X}_{4}+\ln , \beta_{5} \mathrm{X}_{5}+\mathrm{u}_{\mathrm{i}}
$$

Where,

$\mathrm{Y}=$ Output in kilogram (Maize yield in $\mathrm{kg}$ ),

$\mathrm{X}_{1}=$ Farm size in hectares,

$\mathrm{X}_{2}=$ Seed in kilogram $(\mathrm{kg})$,

$\mathrm{X}_{3}=$ Fertilizer in kilogram $(\mathrm{kg})$,

$\mathrm{X}_{4}=$ Family labour in man-day,

$\mathrm{X}_{5}=$ Hired labour in man-day,

, $\mathrm{B}_{1} \ldots \ldots . ., \beta_{5}=$ Regression coefficients,

$\mathrm{U}_{\mathrm{i}}=$ Error term.

Kay (1981)and Shehu (2009) states that in an economic theory, a firm maximizes its profit with respect to an input if the ratio of its marginal value product (MVP) to its marginal factor cost (MFC) is one. A ratio less than unity show overutilization of the resources and profit would be increased by decreasing the quantity used of that input. A ratio greater than unity indicates underutilization of the input and increasing the rate of that input will increase the level of profit of the firm. Marginal value productivities of the inputs can be computed from the results of the estimated production function. Marginal value product (MVP) is defined as the change in the total value as a result of a unit change in the variable input (Olukosi and Ogungbile, 2005). For double-log function, the marginal value product (MVP) is given by the formula:
MVPxi = MPPxi .Py

Where,

MPPxi $=$ is the marginal physical product of the $\mathrm{i}^{\text {th }}$ input, which is given by; $\mathrm{dy} / \mathrm{dxi}$

Py $=$ price per unit of the output (Maize)

dy $=$ change in the unit of output

$\mathrm{dx}=$ change in the unit of input

Marginal factor cost is the addition to total cost resulting from extra unit of input.

MFCxi $=\mathrm{dTC} / \mathrm{dxi}=\mathrm{Pxi}$

Where, 
$\mathrm{dTC}=$ change in total cost

$\mathrm{dXi}=$ change in input $(\mathrm{s})$

$\mathrm{Pxi}=$ is the price

According to Kay (1981); Mshelia et al (1999); Iheanacho et al (2000); Rahman \& Lawal (2003); Stephen et al (2004); Abdu, 1997; Stephen et al (2008), Umar (2011) efficiency of resource (r) is given as:

$$
\mathrm{r}=\mathrm{MVP}
$$

MFC

Where,

$\mathrm{r}=$ efficiency ratio.

$\mathrm{MVP}=$ Marginal value product,

$\mathrm{MFC}=$ Marginal factor cost i.e. unit price of input $\mathrm{X}_{\mathrm{i}}\left(\mathrm{p}_{\mathrm{xi}}\right)$

$\beta \mathrm{i}=\mathrm{Y}$

$\mathrm{X}$

Where,

$\beta_{\mathrm{i}}=$ regression coefficients,

$\mathrm{Y}=$ Arithmetic mean value of output,

$\mathrm{X}_{\mathrm{i}}=$ Arithmetic mean value of input considered

In addition to that, the rule provides that when $r=1$, there is efficient use of a resource; if $r>1$, it indicate underutilization; while if $r<1$, it shows overutilization of resource (Salisu, et. al., 2015).

\section{Socio-economic characteristics of respondents}

\section{Results And Discussion}

Table 1 represents the socio-economic characteristics of the respondent. The study revealed that majority $(90.17 \%)$ of the respondents had formal education implying that majority of the farmers were literate. The ages of $90.17 \%$ of them were between 21-50 years and this agrees with the findings of Sani, et al., 2013 who reported that young farmers dominated Ground nut production and they are in their active stage (between 20-48 years). Male farmers were virtually the same with the female farmers. Majorities (72.50\%) of the farmers were married. In terms of farming experience, majority $(86.67 \%)$ of the respondent had farming experience between 5-20 years with 3 and 22 years as minimum and maximum years of experience, having mean of 18 years and standard deviation of 4.6. Majority $(90.84 \%)$ of the respondents in the study area were small-scale farmers having small fragmented holdings farm size below two hectares. Minimum and maximum size of land cultivated were 0.5 and 8 hectares while 1.5 is the mean and 1.7 as standard deviation. High proportion $(75.00 \%)$ of the farmers had no contact with extension services, showing that they may not get the improved techniques of farming.

Table 1 Socio-Economic Characteristics of the Respondents in the Study Area $(\mathrm{N}=120)$

\begin{tabular}{|c|c|c|c|c|c|c|}
\hline Variable & Freq. & Percentage & Min. & Max. & Mean & Std. deviation \\
\hline \multicolumn{7}{|l|}{ Educational level } \\
\hline No formal education & 13 & 10.83 & & & & \\
\hline Adult and non formal edu & 20 & 16.67 & & & & \\
\hline Primary education & 35 & 29.17 & & & & \\
\hline Secondary education & 37 & 30.83 & & & & \\
\hline Tertiary education & 15 & 12.50 & & & & \\
\hline Total & 120 & 100 & & & & \\
\hline $\operatorname{Age}(y r s)$ & & & 25 & 70 & 45.7 & 8.5 \\
\hline $21-30$ & 24 & 20.00 & & & & \\
\hline $31-40$ & 35 & 29.17 & & & & \\
\hline $41-50$ & 48 & 40.00 & & & & \\
\hline $51-60$ & 12 & 10.00 & & & & \\
\hline$>60$ & 01 & 0.83 & & & & \\
\hline Total & 120 & 100 & & & & \\
\hline \multicolumn{7}{|l|}{ Gender } \\
\hline Male & 62 & 51.67 & & & & \\
\hline Female & 58 & 48.33 & & & & \\
\hline Total & 120 & 100 & & & & \\
\hline \multicolumn{7}{|l|}{ Marital status } \\
\hline Single & 30 & 25.00 & & & & \\
\hline Married & 87 & 72.50 & & & & \\
\hline Divorce & 01 & 0.83 & & & & \\
\hline
\end{tabular}




\begin{tabular}{|c|c|c|c|c|c|c|}
\hline Widowed & 02 & 1.67 & & & & \\
\hline Total & 120 & 100 & & & & \\
\hline Farming experience (yrs) & & & 03 & 22 & 18 & 4.6 \\
\hline$<5$ & 02 & 1.67 & & & & \\
\hline $6-10$ & 12 & 10.00 & & & & \\
\hline $11-15$ & 40 & 33.33 & & & & \\
\hline $16-20$ & 50 & 41.67 & & & & \\
\hline$>20$ & 16 & 13.33 & & & & \\
\hline Total & 120 & 100 & & & & \\
\hline Farm size (ha) & & & 0.5 & 8 & 1.5 & 1.7 \\
\hline$<1$ & 12 & 10.00 & & & & \\
\hline $1-2$ & 97 & 80.84 & & & & \\
\hline $3-4$ & 10 & 8.33 & & & & \\
\hline$>5$ & 01 & 0.83 & & & & \\
\hline Total & 120 & 100 & & & & \\
\hline Extension contact & & & & & & \\
\hline Yes & 30 & 25.00 & & & & \\
\hline No & 90 & 75.00 & & & & \\
\hline Total & 120 & 100 & & & & \\
\hline
\end{tabular}

Source: survey data, 2015

\section{Production Input-Output Relationship}

The analysis revealed that $79.7 \%$ of the variation in output of Maize in the study area was explained by the factor inputs as shown by the value of Adjusted $\mathrm{R}^{2}(79.7)$. All the variables have positive coefficients except family labour. They all affect output significantly except land. This implies that an increase in the quantity of input will result to an increase in output; and for factor inputs that are significant, they are the major determinants of output (Salisu, et al., 2015). The negative sign family labour signifies an inverse relationship with output in production. Maize production in the study area has an increasing return to scale from the sum of elasticity of production (1.747).

Table 2: Estimated Cobb-Douglas Production Function for Maize

\begin{tabular}{|c|c|c|c|}
\hline Factor inputs & Regr & & t-value \\
\hline Constant & $0.480^{*} *$ & 3.210 & \\
\hline Land $\left(\mathrm{X}_{1}\right)$ & 0.092 & 5.460 & \\
\hline Seed $\left(X_{2}\right)$ & $0.382 * * *$ & 4.732 & \\
\hline Fertilizer $\left(\mathrm{X}_{3}\right)$ & $0.584 * * *$ & 3.530 & \\
\hline Family labour $\left(\mathrm{X}_{4}\right)$ & $-0.192 * *$ & -2.99 & \\
\hline Hired labour $\left(\mathrm{X}_{5}\right)$ & $0.493 * *$ & 3.518 & \\
\hline $\mathrm{R}^{2}$ & 81.16 & & \\
\hline Adjusted $\mathrm{R}^{2}$ & & & \\
\hline F-ratio & $34.70 * * *$ & & \\
\hline Standard error (S.E.) & 0.20532 & & \\
\hline Elasticity of production (EP) & 1.747 & & \\
\hline
\end{tabular}

Source: survey data, 2015

*** Significant at 1\%; ** Significant at 5\%; * Significant at 10\%

\section{Resource Productivity in Maize Production}

The estimated Cobb-Douglas production function is given in Table 2 above. The lead equation is:

$\ln Y=\ln 0.480+0.092 \ln X_{1}+0.382 \ln X_{2}+0.584 \ln X_{3}-0.192 \ln X_{4}+0.4931 \ln X_{5}$

It can be seen from the table 3 below that an extra unit of seed input used in the production of Maize would result in to an addition of $20.56 \mathrm{~kg}$ and $\mathbf{2} 2,261$ to output and revenue respectively. Similarly, a unit increase in fertilizer raised output by $10.10 \mathrm{~kg}$ and revenue by $\mathbf{1} 1,122$. Hired labour has least contribution of $2.05 \mathrm{~kg}$ and $\mathbf{N}$ 225.50 to output and revenue. The negative sign associated with family labour result in inverse contribution to output and total revenue implying that use of extra unit of family labour will lead to decline in output and total revenue of Maize in the study area.

\section{Efficiency of Resource Use in Small-Scale Maize Production}

From the results shown in Table 3, seed and fertilizer were underutilized in Maize production, whereas hired and family labour were over used. This means that Maize production in the study area was not efficient. This finding agrees with Jirgi, 2002; Umar, 2011 and is contrary to Hamidu, 2002 who revealed that rice farmers in Bauchi State were efficient in labour utilization. Hence, profit could be enhanced by increasing the quantity used of seed and fertilizer inputs. Hired and family labour should be reduced to optimum level for increase output and total revenue respectively. 
Table 3: Marginal Physical Product and Resource-use Efficiency in Maize Production

\begin{tabular}{|lcc|c|c|c|}
\hline Inputs & MPP $(\mathbf{k g})$ & MVP (N) & MFC (N) & MVP/MFC \\
\hline Seed $\left(\mathrm{X}_{2}\right)$ & 20.56 & 2,261 & 120 & & 18.84 \\
Fertilizer $\left(\mathrm{X}_{3}\right)$ & 10.10 & 1,120 & 270 & & 4.15 \\
Family labour $\left(\mathrm{X}_{4}\right)$ & -0.22 & -12.32 & 210 & & -0.059 \\
Hired labour $\left(\mathrm{X}_{5}\right)$ & 2.05 & 225.50 & 470 & & 0.480 \\
\end{tabular}

Source: survey data, 2015

\section{Constrains To Maize Production}

Several problems that have affected Maize farmers are giving in table 4. It shows that the major problems confronting Maize farmers includes high cost of inputs (77.50\%), untimely disbursement of inputs/credit $(62.50 \%)$, inadequate extension services $(59.17 \%)$, unstable produce price $(41.67 \%)$, high incidence of striga $(35.00 \%)$, draught $(33.33 \%)$, inadequate credit facilities $(31.67 \%)$, depletion of soil fertility $(25.93 \%)$, insect pest \& disease $(25.00 \%)$, and inadequate high yielding varieties $(14.18 \%)$. These constrains militates against Maize production in the study area and it agrees with Mshelia et al 1999, Stephen et al, 2004; Stephen et al, 2008.

Table 4: Constrains to Maize Production faced by the farmers

\begin{tabular}{|lccc|c|}
\hline Problems & & Freq. & Percentage Rank \\
\hline Draught & 40 & 33.33 & 6 & \\
High incidence of striga & 42 & 35.00 & 5 & \\
Insect pest \& disease & 30 & 25.00 & 9 & \\
Inadequate credit facilities & 38 & 31.67 & 7 & \\
Depletion of soil fertility & 35 & 29.17 & 8 & \\
High cost of farm inputs & 93 & 77.50 & 1 & \\
Untimely disbursement of inputs/credit & 75 & 62.50 & 2 & \\
Inadequate extension services & 71 & 59.17 & 3 & \\
Inadequate high yielding varieties & 20 & 16.67 & 10 & \\
Unstable produce price & 50 & 41.67 & 4 & \\
\hline
\end{tabular}

Source: survey data, 2015

NB: Multiple responses allowed

\section{Conclusion And Recommendations}

Efficiency of resource-use in small-scale Maize production in Tafawa-balewa local government area of Bauchi State was examined in this study. Production inputs such as seed, fertilizer, family and hired labour affected output significantly. The resources were not efficiently utilized. So, farm profit could be enhanced by using more of seed and fertilizer, less of family and hired labour. It was recommended that farm inputs, especially improved seeds and fertilizer should be supplied to farmers at the right time and at cost that is within their reach. Farmers should be educated to apply the right quantity of fertilizer through extension service. Farmers should try to reduce labour cost and improve food productivity.

\section{References}

[1]. Abdu, Z. (1997). Economics of resource-use in small-scale soybean production system in Bauchi state. Unpublished M. Sc Thesis, Abubakar Tafawa Balewa University, Bauchi. 83 Pp.

[2]. Adebowale, S. (2014). Agricultures contribution to Nigeria's economy in 2012. A report retrieved 10/11/2015 from www.theageonline.com.ng/agriculture-contributed-n348-7b-nigerias-economy-2012-report/

[3]. Adedeji, I. A, Fabiyi, E. F, Adegun G. T and Oyetunde, T. O (2015). Data Environment Analysis Approach as a Compliment to Resource-use Efficiency Among Rice Farmers in Ogbomoso Agricultural zones of Oyo State, Nigeria. Journal of World Economic Research, 2015; 4 (2): 23-31

[4]. Adesoji, A. G., Abubakar, I. U., Tanimu, B., \& Labe, D. A. (2013). Influence of incorporated short duration legume fallow and nitrogen on maize (Zea mays L.) growth and development in northern guinea savannah of Nigeria.American-Euroasian J. Agric. And Env. Sci., 13(1), 57-68.

[5]. Alimi, T. (2000), Resource Use Efficiency in Food Crop Production in Oyo State of Nigeria. Journal of Agriculture and Environment,1(1): Pp. 1-7.

[6]. Amaza, P. S. and Olayemi, J. K. (2002). Analysis of Technical Inefficiency in Food Crop production in Gombe State, Nigeria. Journal of Applied Economic Letters. 9 (1) pp. 51-54.

[7]. Amos, R. N., Jens, B. A., \& Symon, M. (2012). On farm evaluation of yield and economic benefits of short term maize legume intercropping systems under conservation Agriculture in Malawi. Field crop research, 132, 149-157.

[8]. Dado, R. G. (1999). Nutritional benefit of specialty Maize grain Hybrid in Dairy diets. Journal of Animal Science, $197-207$.

[9]. Hamidu, B. M. (2002). Economics of resource use in small-scale rice farms: a case study of labour utilisation in Dass Local Government Area, Bauchi State. Unpublished Ph.D, Thesis. Abubakar Tafawa Balewa University, Bauchi. 99-100 Pp.

[10]. Iheanacho A.C.; Olukosi J.O.; and Ogunbile A.O. (2000). "Economic Efficiency of Resource Use in Millet Based Cropping System in Borno State of Nigeria, Nigerian Journal of Tropical Agriculture, 2(2): Federal University of Technology, 33-42.

[11]. Jirgi A. J. (2002). Analysis of resource-use efficiency in small scale sorghum production: A case study of Zuru Local Government Area Kebbi State. Unpublished M. Sc Thesis. Abubakar Tafawa Balewa University Bauchi, Nigeria. 2-56 pp. 
[12]. Kalu,C. V. (1994). The Nigerian Condition: Arthur Nwankwo's View Point and Blue Prints. Lagos, Nigeria.: Fourth Dimension Publishers, $248 \mathrm{p}$.

[13]. Kay, R. D. (1981). Farm Management Planning, Control and Implementation. New York, U.S.A.: McGraw-Hill, Book Company, 350-358p.

[14]. Maluleke, M. H., Bediako, A. A., \& Ayisi, K. K. (2005). Influence of maize-lablab intercropping on Lepidopterous stem borer infestation in maize. J. Entom., 98, 384-388. http://dx.doi.org/10.1603/0022-0493-98.2.384

[15]. Mshelia, S.I; Jongur, A. A. U; Polycarp, M. I, (1999). Economic Profitability of Cowpea Production in Adamawa State: A case study of small-holder farmers in Yola-North and South Local Government Areas in S. Kushawaha; I. A. Adegbola; T. O. Oseni; B. M. Auwalu and I. S. Butswat (eds). Agricultural Development in the $21^{\text {st }}$ Centuary: Concepts and Strategies. Proceedings of the $14^{\text {th }}$ Annual Conference of Farm Management Association of Nigeria. Pp. 47-50.

[16]. NPC (2006), Nigerian National Population Census Report, National Population Commission, Abuja. Pp 34-39.

[17]. Olayide S.O. and Heady E.O. (1982). Introduction to Agricultural Economics. Ibadan University Press, Ibadan, Nigeria. Pp. 319.

[18]. Olukosi, J. O. and Ogungbile A.O. (2005). Introduction to Production Economics: Principles and Applications. Zaria, Nigeria.: Agitab Publishers limited, 112p.

[19]. Rahman S.A. and Lawal A.B. (2003). "Economic analysis of maize-based copping systems in Giwa Local Government Area of Kaduna State, Nigeria”. International Journal of Agricultural Science, Sciences, Environment and Technology, 3 (2): 139-148p.

[20]. Sani, A.,Taru, V. B., Kyagya, I. Z., Mshelia, S. I., \& Adebayo, E. F. (2013). Economic efficiency of resource use in Groundnut production in Northeastern States of Nigeria. World Journal of Agricultural Sciences, 4(5), 896-900.

[21]. Salisu, A. B., Shakuga, J. E. and Dagi, M. B. (2015). Profitability Analysis of Small scale Egg Production in Bauchi Metropolis, Bauchi State, Nigeria. Agriculture: A Review Focus for Economic Development in Nigeria. Proceedings of the $29^{\text {th }}$ Annual Conference of Farm Management Association of Nigeria, Dutse 2015. Pp. 524.

[22]. Stephen, J.; Mshelia, S. I. and Kwaga, B. T. (2004). Resource-use Efficiency in Cowpea Production in the North-East Zone of Adamawa State, Nigeria. http://www.verypdf.com/to remove this watermark.

[23]. Stephen, J.; Mshelia, S. I. and Tashikalma, A. K. (2008). Economic Efficiency of Resource-use in Cowpea Production in the Northern part of Adamawa State, Nigeria. Journal of League of Researchers in Nigeria (JOLORN) 9 (1):130-133.

[24]. Umar, S. A. (2010). Resource-use Efficiency in Small-scale Cowpea Production in Katagum Local Government Area of Bauchi State, Journal of Issues in Technical Teacher Education, Federal College of Education Technical Potiskum, Yobe State- Nigeria. 6 (1):117-119.

[25]. Umar, S. A. (2011). Resource-use Efficiency in Small-scale Cowpea Production in Katagum Zone of Bauchi State. Unpublished M.Sc. Thesis, Bayero University, Kano-Nigeria P.86

[26]. Umar, S. A. (2011). Resource-use Efficiency in Small-scale Sorghum Production: A Caseb Study of Katagum Local Government of Bauchi State. Journal of Arid Agriculture 20 (1) 0189-7551

[27]. Undie, U. L., Uwah, D. F., \& Attoe, E. E. (2012). Effect of intercropping and crop arrangement on yield and productivity of late season Maize/soybean mixtures in the humid environment of South Southern Nigeria. Journal of Agricultural Science, 4(4), 37-50. http:dx.doi.org/10.5539/jas.v4n4p37 